\title{
A Comparative Study of Player and Non- Player Students in Relation to Mental Health
}

Gahlawat $^{1}$, O.P. \& Gahlawat ${ }^{2}$, P.

${ }^{1}$ Prof, Department of Physical Education, Kurukshetra University.

${ }^{2}$ Assistant Professor of Physical Education \& Sports, Govt. College for Girls, Chandigarh.

\section{Abstract}

The objective of this study was "To examine mental health dimensions between player and non- player students". Researcher took 50 boys and 50 girls ranging from 17 to 21 years for the study. In the present study sex and type of students have been treated as independent variable and mental health as dependent variable. The respective groups of boys and girls were adminstered the mental health inventory by Jagdish and Srivastava (1983). It was observed that male player subjects are found more positive self-evaluation, integration of personality, autonomy and environmental mastery than male non player subject, and over all mental health there is significant difference between male player and male non -player subjects. Female Player subjects are found more positive self-evaluation, integration of personality, autonomy, grouporiented attitudes and environmental mastery than female non player subjects, and over all mental health, there is significant difference between female player and female non -player subjects.

Keywords: Mental health, male players, female players

\section{Introduction:}

For some time now, it has been common knowledge that exercise is good for one's physical health. It has only been in recent years, however, that it has become commonplace to read in magazines and health newsletters that exercise can also be of value in promoting sound mental health. The World Health Organization defines mental health as "a state of well-being in which the individual realizes his or her own abilities, can cope with the normal stresses of life, can work productively and fruitfully, and is able to make a contribution to his or her community" (Stephen et al, 2005). Neither mental nor physical health can exist alone. Mental, physical, and social functioning are interdependent. In recent years, there has been evidence of disturbingly high rates of mental ill-health among adolescents and even younger children, ranging from low-self-esteem, anxiety and depression to eating disorders, substance abuse and suicide (Sallis and Owen, 1999). Research suggests two ways in which physical activities can contribute to mental health in adolescents. Firstly, there is fairly consistent evidence that regular activity can have a positive effect upon boys' and girls' psychological well-being. Secondly, research has indicated that physical activity can contribute to the reduction of problematic levels of anxiety and depression. Evidence is beginning to be gathered for exercise as a treatment for clinical depression, with studies finding that physical activity is as effective a treatment as anti-depressants (Dimeo et al., 2001), and psychotherapy (Martinsen, 1994). Similarly, a variety of nonclinical 
studies have found that higher levels of activity were related to lower rates of depression (Hassmen et al., 2000). A position statement of the International Society of Sport Psychology (Singer, 1992) drew out numerous mental health benefits of physical activity from the research literature, including reduced state anxiety, neuroticism and anxiety, mild to moderate depression, and various kinds of stress. A review of current literature indicates that people who participate in sports and organized recreational activity enjoy better mental health, are more alert, and more resilient against the stresses of modern living. Participation in recreational groups and socially supported physical activity is shown to reduce stress, anxiety and depression, and reduce symptoms of Alzheimer's disease (Carcach \& Huntley, 2002).

\section{Hypotheses}

1. There exists significant difference in the level of mental health between the male player students and the male non-player students.

2. There exists significant difference in the level of mental health between the female player students and the female non-player students.

\section{Materials \& Methods}

Selection of the sample

The present study was conducted on 50 Boys and 50 Girls ranging in age from 17-21 years. A total of 100 subjects (player and non player college going students) were selected for the present research study. The sample selection method was used as purposive sampling technique. The area was limited to Chandigarh. The detailed break-up of the sample is given below:

\begin{tabular}{lccc}
\hline Area & $\begin{array}{c}\text { Male } \\
(\mathbf{N})\end{array}$ & $\begin{array}{c}\text { Female } \\
(\mathbf{N})\end{array}$ & $\begin{array}{c}\text { Total } \\
(\mathbf{N})\end{array}$ \\
\hline Player & $\mathbf{2 5}$ & $\mathbf{2 5}$ & $\mathbf{5 0}$ \\
Non- & $\mathbf{2 5}$ & $\mathbf{2 5}$ & $\mathbf{5 0}$ \\
$\begin{array}{l}\text { Player } \\
\text { Total }\end{array}$ & $\mathbf{5 0}$ & $\mathbf{5 0}$ & $\mathbf{1 0 0}$ \\
\hline \multicolumn{2}{l}{ Independent } & Variables: $a)$ Sex $b$ ) & Type of
\end{tabular}
students.

Dependent Variables: Mental Health.

Selection of research tool: Mental health inventory (Jagdish and Srivastav, 1983).

The data was collected from the various colleges and sports training centers. The subjects were first explained about the aim of the research study, thereafter mental health inventory given by Jagdish and Srivastav (1983) was administered. The subjects' were assured confidentiality of their responses.

\section{Results \& Discussion}

Table-1: Table-2: Statistical Comparison of Mental Health Inventory components between male player and non- player students.

\begin{tabular}{|c|c|c|c|c|c|c|}
\hline Area & Type & $\mathbf{N}$ & Mean & S.D. & $\begin{array}{l}\text { t- } \\
\text { value }\end{array}$ & Sign. \\
\hline \multirow{2}{*}{ 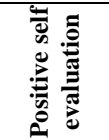 } & Players & 25 & 33.12 & 3.72 & \multirow[b]{2}{*}{2.19} & \multirow[b]{2}{*}{0.05} \\
\hline & $\begin{array}{l}\text { Non- } \\
\text { Player }\end{array}$ & 25 & 31.08 & 2.81 & & \\
\hline \multirow{2}{*}{ 을 } & Players & 25 & 25.88 & 2.86 & \multirow[b]{2}{*}{0.72} & \multirow[b]{2}{*}{ NS } \\
\hline & $\begin{array}{l}\text { Non- } \\
\text { Player }\end{array}$ & 25 & 25.20 & 3.78 & & \\
\hline \multirow{2}{*}{ 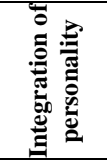 } & Players & 25 & 39.32 & 3.66 & \multirow[b]{2}{*}{3.50} & \multirow[b]{2}{*}{0.01} \\
\hline & $\begin{array}{l}\text { Non- } \\
\text { Player }\end{array}$ & 25 & 35.36 & 4.31 & & \\
\hline \multirow{2}{*}{ 总 } & Players & 25 & 20.52 & 1.96 & \multirow[b]{2}{*}{2.32} & \multirow[b]{2}{*}{0.01} \\
\hline & $\begin{array}{l}\text { Non- } \\
\text { Player }\end{array}$ & 25 & 19.32 & 2.44 & & \\
\hline \multirow{2}{*}{ 气 } & Players & 25 & 34.68 & 4.34 & \multirow[b]{2}{*}{0.64} & \multirow[b]{2}{*}{ NS } \\
\hline & $\begin{array}{l}\text { Non- } \\
\text { Player }\end{array}$ & 25 & 33.96 & 3.55 & & \\
\hline \multirow{4}{*}{ 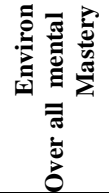 } & Players & 25 & 33.96 & 2.52 & \multirow[b]{2}{*}{4.04} & \multirow[b]{2}{*}{0.01} \\
\hline & $\begin{array}{l}\text { Non- } \\
\text { Player }\end{array}$ & 25 & 30.68 & 3.17 & & \\
\hline & Players & 25 & 187.48 & 7.14 & \multirow[b]{2}{*}{5.50} & \multirow[b]{2}{*}{0.01} \\
\hline & $\begin{array}{l}\text { Non- } \\
\text { Player }\end{array}$ & 25 & 175.40 & 8.35 & & \\
\hline
\end{tabular}


Table 1 shows difference between the groups of male player and male non player subjects on the various factors of Mental Health Inventory. Only four factors are showing significant difference between the two groups at the 0.05 and 0.01 levels on $48 \mathrm{df}$ grade. It is concluded that player subjects are found more positive in self-evaluation $(\mathrm{t}=2.19$, $\mathrm{p}<0.05)$, integration of personality $(\mathrm{t}$ $=3.50, \quad \mathrm{p}<0.01), \quad$ autonomy $\quad(\mathrm{t}=2.32$, $\mathrm{p}<0.01)$ and environmental mastery $(\mathrm{t}$ $=4.04, \mathrm{p}<0.01$ ), than the non player subjects, and over all mental health, there is significant difference between male player and male non - player subjects. The obtained ' $t$ ' values of these groups are 5.50. In order to be significant at 0.05 , the minimum required value of ' $\mathrm{t}$ ' is 2.02 . While at 0.01 level it is 2.70. Since the obtained value is larger than which is required to be significant at 0.01 level.

Table-2: Statistical Comparison of Mental Health Inventory components between female player and non- player students.

\begin{tabular}{|c|c|c|c|c|c|c|}
\hline Area & Type & $\mathbf{N}$ & Mean & S.D. & $\begin{array}{c}\text { t- } \\
\text { value }\end{array}$ & Sign. \\
\hline \multirow{2}{*}{ 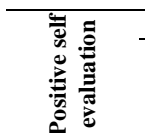 } & Players & 25 & 32.24 & 3.02 & \multirow[b]{2}{*}{3.07} & \multirow[b]{2}{*}{0.01} \\
\hline & $\begin{array}{l}\text { Non- } \\
\text { Player }\end{array}$ & 25 & 29.36 & 3.59 & & \\
\hline \multirow{2}{*}{ 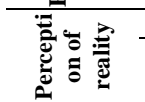 } & Players & 25 & 24.80 & 3.84 & \multirow[b]{2}{*}{0.59} & \multirow[b]{2}{*}{ NS } \\
\hline & $\begin{array}{l}\text { Non- } \\
\text { Player }\end{array}$ & 25 & 24.12 & 4.58 & & \\
\hline \multirow{2}{*}{ 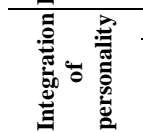 } & Players & 25 & 37.12 & 5.58 & \multirow[b]{2}{*}{2.06} & \multirow[b]{2}{*}{0.05} \\
\hline & $\begin{array}{l}\text { Non- } \\
\text { Player }\end{array}$ & 25 & 33.84 & 5.64 & & \\
\hline \multirow{2}{*}{ 嶽 } & Players & 25 & 18.36 & 2.66 & \multirow[b]{2}{*}{3.19} & \multirow[b]{2}{*}{0.01} \\
\hline & $\begin{array}{l}\text { Non- } \\
\text { Player }\end{array}$ & 25 & 16.24 & 1.98 & & \\
\hline \multirow{2}{*}{ 色总 } & Players & 25 & 35.20 & 3.85 & \multirow[b]{2}{*}{2.88} & \multirow[b]{2}{*}{0.01} \\
\hline & $\begin{array}{l}\text { Non- } \\
\text { Player }\end{array}$ & 25 & 31.84 & 4.37 & & \\
\hline \multirow{2}{*}{ 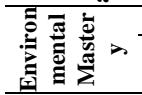 } & Players & 25 & 33.12 & 4.02 & \multirow[b]{2}{*}{2.16} & \multirow[b]{2}{*}{0.05} \\
\hline & $\begin{array}{l}\text { Non- } \\
\text { Player } \\
\end{array}$ & 25 & 30.84 & 3.39 & & \\
\hline \multirow{2}{*}{$\begin{array}{l}\text { न } \\
\vdots \\
0 \\
0\end{array}$} & Players & 25 & 180.04 & 8.34 & \multirow[b]{2}{*}{4.89} & \multirow[b]{2}{*}{0.01} \\
\hline & $\begin{array}{l}\text { Non- } \\
\text { Players }\end{array}$ & 25 & 166.80 & 10.65 & & \\
\hline
\end{tabular}

Table 2 shows difference between the groups of female player and female non -player subjects on the various factors of M. H. Inventory. Five factors out of six are showing significant difference between two groups at the 0.05 and 0.01 level on $48 \mathrm{df}$ grade. It is concluded that player subjects are found more positive self evaluation $(\mathrm{t}=3.07, \mathrm{p}<0.01)$, integration of personality $(\mathrm{t}=2.06$, $\mathrm{p}<0.05)$, autonomy $(\mathrm{t}=3.19)$, group oriented attitudes $(\mathrm{t}=2.88, \mathrm{p}<0.01)$ and environmental mastery $(\mathrm{t}=2.16, \mathrm{p}<0.05)$ than non player subjects, and over all mental health there is significant difference between female player and female non -player subjects. The obtained ' $t$ ' value of these groups are 5.32. In order to be significant at 0.05 , the minimum required value of ' $t$ ' is 2.02 . While at 0.01 level it is 2.70 . Since the obtained value is larger than which is required to be significant at 0.01 level.

\section{Conclusion}

Male player subjects are found more positive self-evaluation, integration of personality, autonomy and environmental mastery than male non player's subjects and over all mental health there is significant difference between male player and male non -player subjects.

Female Player subjects are found more positive self-evaluation, integration of personality, autonomy, group-oriented attitudes and environmental mastery than female non player subjects and over all mental health there is significant difference between female player and female non -player subjects.

\section{Discussion}

The aim of the present study was to examine mental health dimensions 
between player and non- player students. It was hypothesized that there exists significant difference in the level of mental health between the male player students and the male non-player students. It was also hypothesized that there exists significant difference in the level of mental health between the female player students and the female non-player students. Findings of the present study clearly indicated that -Male player subjects are found more positive in selfevaluation, integration of personality, autonomy and environmental mastery than male non player subjects, and in over all mental health there is significant difference between male player and male non -player subjects. These results are also in agreement with the conclusions reached by Morgan (1984), Humphrey et al (2000) and Stephen et al (2005). Female Player subjects are found more positive in self-evaluation, integration of personality, autonomy, group-oriented attitudes and environmental mastery than female non player subjects, and over all mental health, there is significant difference between female player and female non -player subjects. The results of the present study are partially supported by the findings of Mckelvie et al. (1981), Bailey and Moulton (1999) and Hossein et al. (2011). The research literature suggests that for many variables there is now ample evidence that a definite relationship exists between exercise and improved mental health. This is particularly evident in the case of a reduction of anxiety and depression. For these topics, there is now considerable evidence derived from over hundreds of studies with thousands of subjects to support the claim that "exercise is related to a relief in symptoms of depression and anxiety." Sports and physical exercise is related not only to a relief in symptoms of depression and anxiety but it also seems to be beneficial in enhancing self-concept, self-efficacy, confidence, feeling of worth-whileness, ability to understand, ability to get along with others, work with others and ability to take responsibilities and capacity for adjustment. None of these relationships is the result of a single study. They are based on most, if not all, of the available research in the English language at the time the meta-analytic review was published. The overall positive patterns of the meta-analytic findings for these variables lends greater confidence that exercise has an important role to play in promoting sound mental health.

\section{References}

Bailey, K., Moulton, M., and Moulton, P. 1999. Athletics as a predictor of self-esteem and approval motivation. The Sports Journal, 2(2): 1-5.

Carcach, C. Y., Huntley, C. 2002. Community Participation and Regional Crime. Australian Institute of Criminology. Trends and Issues in Crime and Criminal Justice Number 222. (Canberra: AIC).

Dimeo, F., Bauer, M., Varahram, I., Proest, G. and Halter, U. 2001. Benefits of Aerobic Exercise in Patients Withmajor Depression: a pilot study. Brit. J. Sports Med., 35: 114-117.

Hassmen, P., Koivula, N. and Uutela, A. 2000. Physical Exercise and Psychological Wellbeing: a population studyin Finland. Prev. Medicine, 30(1): 17-25.

Taylor, M., Pietrobon, R., Pan, D., Huff, M. and Higgins, L. 2004. Healthy People 2010 Physical Activity Guidelines and Psychological Symptoms: evidence from a large nationwide database. J. Phys. Activity and Health, 1: 114-130.

Hossein, P. Z., Farhad, R., Fatemeh, M. 2011.Comparing the Mental Health of the Athletic and Non- athletic Physicallydisabled People. Iran. J. Health and Physical Activity, 2(1): 6-10.

Humphrey, J. H., Yow, D. A. and Bowden, W. W. 2000. Stress in college athletics: Causes, 
consequences, coping. Binghamton, NY: The Haworth Half-Court Press.

Jagdish and Srivastava, A. K. 1983. Mental Health Inventory. Varanasi Manavaigyanik Sansthan.

Martinsen, E. 1994. Physical Activity and Depression: clinical experience. Acta Psychiatrica Scandinavica, 377, pp. 23-27.

McKelvie, S. J., Simpson-Housley, P., and Valliant, P. M. 1981. Personality in athletic and non-athletic college groups. Percep. Motor Skills, 52(3): 963-966.

Morgan, W.P. 1984. Selected psychological factors limiting performance: A mental health model. American Academy of Physical Education Papers, 18, 70-80.

Sallis, J. and Owen, N. 1999 Physical Activity and Behavioral Medicine. Thousand Oaks, US: Sage.

Singer, R. 1992. Physical Activity and Psychological Benefits: a position statement of the International Society of Sport Psychology (ISSP). The Sports Psychologist, 6, pp. 199-203.

Stephen, D. E., Humphrey, S. B., Ngcobo, D. J., Edwards and Palavar, K. 2005. Exploring the relationship between physical activity, Psychological well-being and physical selfperception In different exercise groups. South African Journal for Research in Sport, Physical Education and Recreation, 27(1): 75-90.

World Health Organization 2005. Promoting Mental Health: Concepts, Emerging evidence, Practice: A report of the World Health Organization, Department of Mental Health and Substance Abuse in collaboration with the Victorian Health Promotion Foundation and the University of Melbourne. World Health Organization. Geneva.

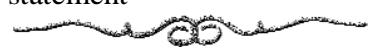

